\title{
Intracellular calcium release modulates polycystin-2 trafficking
}

\author{
Ayako Miyakawa ${ }^{1,2}$, Cristián Ibarra', Seth Malmersjö ${ }^{1}$, Anita Aperia ${ }^{3}$, Peter Wiklund ${ }^{2}$ and Per Uhlén ${ }^{1 *}$
}

\begin{abstract}
Background: Polycystin-2 (PC2), encoded by the gene that is mutated in autosomal dominant polycystic kidney disease (ADPKD), functions as a calcium $\left(\mathrm{Ca}^{2+}\right)$ permeable ion channel. Considerable controversy remains regarding the subcellular localization and signaling function of PC2 in kidney cells.

Methods: We investigated the subcellular PC2 localization by immunocytochemistry and confocal microscopy in primary cultures of human and rat proximal tubule cells after stimulating cytosolic $\mathrm{Ca}^{2+}$ signaling. Plasma membrane (PM) $\mathrm{Ca}^{2+}$ permeability was evaluated by Fura-2 manganese quenching using time-lapse fluorescence microscopy.
\end{abstract}

Results: We demonstrated that PC2 exhibits a dynamic subcellular localization pattern. In unstimulated human or rat proximal tubule cells, PC2 exhibited a cytosolic/reticular distribution. Treatments with agents that in various ways affect the $\mathrm{Ca}^{2+}$ signaling machinery, those being ATP, bradykinin, ionomycin, CPA or thapsigargin, resulted in increased PC2 immunostaining in the PM. Exposing cells to the steroid hormone ouabain, known to trigger $\mathrm{Ca}^{2+}$ oscillations in kidney cells, caused increased PC2 in the PM and increased PM Ca ${ }^{2+}$ permeability. Intracellular $\mathrm{Ca}^{2+}$ buffering with BAPTA, inositol 1,4,5-trisphosphate receptor ( $\left(\mathrm{InSP}_{3} \mathrm{R}\right.$ ) inhibition with 2-aminoethoxydiphenyl borate (2-APB) or $\mathrm{Ca}^{2+} / \mathrm{Calmodulin}^{-}$ dependent kinase inhibition with KN-93 completely abolished ouabain-stimulated PC2 translocation to the PM.

Conclusions: These novel findings demonstrate intracellular $\mathrm{Ca}^{2+}$-dependent PC2 trafficking in human and rat kidney cells, which may provide new insight into cyst formations in ADPKD.

Keywords: Polycystin-2, Protein trafficking, Calcium signaling, Kidney cells, Autosomal dominant polycystic kidney disease

\section{Background}

Autosomal dominant polycystic kidney disease (ADPKD) is the most commonly inherited monogenetic disease, affecting more than 1 in 1000 live births, causing renal failure [1]. ADPKD is caused by mutation in two associated proteins, polycystin-1 or -2 (PC1 and PC2), which are essential for the formation and maintenance of a proper structure of the renal tubule. These mutations in PC1 and PC2 are responsible for approximately $85 \%$ and $15 \%$ of all ADPKD cases, respectively [2]. It is well established that $\mathrm{PC} 2$ acts as an ion channel permeable to calcium ions $\left(\mathrm{Ca}^{2+}\right)$ [3]. Interestingly, loss of PC2 channel function and subsequent impaired $\mathrm{Ca}^{2+}$ signaling may contribute to ADPKD pathogenesis [4]. A controversial aspect of PC2-mediated signaling in ADPKD is whether

\footnotetext{
* Correspondence: per.uhlen@ki.se

'Department of Medical Biochemistry and Biophysics, Karolinska Institutet, Stockholm SE-171 77, Sweden

Full list of author information is available at the end of the article
}

this protein is expressed in the endoplasmic reticulum (ER) or in the plasma membrane (PM). The amount of PC2 present in the ER, where it functions as a $\mathrm{Ca}^{2+}$-activated intracellular $\mathrm{Ca}^{2+}$ release channel [3], is significantly larger than the amount of PC2 expressed in the $\mathrm{PM}$, where it functions as a non-selective cation channel $[5,6]$. In addition, $\mathrm{PC} 2$ has also been documented in the primary cilium of kidney epithelial cells, where it contributes to the mechano-sensing machinery by mediating $\mathrm{Ca}^{2+}$ entry in response to flow rate changes [7]. Nevertheless, the exact function and mechanism of $\mathrm{PC} 2$ activation in the cilium and/or other subcellular organelles remain largely unknown.

$\mathrm{Ca}^{2+}$ signaling is a vital mechanism in many cell types, controlling diverse cellular processes, such as: secretion, mechano-transduction, cell death, gene expression, or proliferation (for review see [8]). Under certain conditions, via a sophisticated interplay between $\mathrm{Ca}^{2+}$ channels and
C Biomed Central

(c) 2013 Miyakawa et al.; licensee BioMed Central Ltd. This is an Open Access article distributed under the terms of the Creative Commons Attribution License (http://creativecommons.org/licenses/by/2.0), which permits unrestricted use, distribution, and reproduction in any medium, provided the original work is properly cited. 
transporters located in the PM and/or on the membrane of internal organelles, such as the ER, sustained oscillatory $\mathrm{Ca}^{2+}$ signaling can occur [9]. These $\mathrm{Ca}^{2+}$ oscillations encode important information in their frequency and amplitude, which is decoded by cells using different $\mathrm{Ca}^{2+}$-effectors, such as protein kinases, phosphatases, proteases or transcription factors, which in turn regulate adaptive cellular responses. Intracellular $\mathrm{Ca}^{2+}$ signaling mishandling is involved in the pathogenesis or progression of several disease conditions and particularly in kidney disease, where intracellular $\mathrm{Ca}^{2+}$ signaling appears to be linked to cystic formation during ADPKD [10].

In the current study, we investigated the dynamic nature of $\mathrm{PC} 2$ localization in primary human and rat kidney proximal tubule cells. We found that PC2 translocates from a basal, reticular-like localization to a PM localization when cells were challenged with agents that raise the basal concentration of intracellular $\mathrm{Ca}^{2+}$. $\mathrm{PC} 2$ trafficking was inhibited either by intracellular $\mathrm{Ca}^{2+}$ release blockers or by inhibitors of key $\mathrm{Ca}^{2+}$-dependent proteins. Taken together, these results demonstrate that PC trafficking in kidney cells is regulated by intracellular $\mathrm{Ca}^{2+}$ and may contribute to the general understanding of ADPKD.

\section{Methods}

\section{Cells cultures}

Primary cultures of rat proximal tubule ( $\mathrm{rPT}$ ) cells were prepared as described previously [11]. Briefly, kidneys from 20-day-old female Sprague Dawley rats were used to prepare rPT cells. Cells were cultured in supplemented DMEM (20 mM Hepes, $24 \mathrm{mM}$ $\mathrm{NaHCO}_{3}, 10 \mathrm{mg} / \mathrm{ml}$ penicillin, $10 \mathrm{mg} / \mathrm{ml}$ streptomycin and $10 \%$ fetal bovine serum (FBS)) on glass coverslips for $48-72 \mathrm{~h}$ in $5 \% \mathrm{CO}_{2}$ at $37^{\circ} \mathrm{C}$. Cells were starved in 1\% FBS and cultured in the absence of antibiotics for $24 \mathrm{~h}$ before the experiment. Primary cultures of human proximal tubule (hPT) cells were prepared as described. Briefly, approximately $10 \mathrm{~g}$ of fresh renal tissue, obtained from human nephrectomy samples, was dissected, and the obtained cortex was minced and then enzymatically digested with $1 \mathrm{mg} / \mathrm{ml}$ of type 4 collagenase. The resulting suspension was filtered and then centrifuged at $200 \mathrm{x} \mathrm{g}$ for $5 \mathrm{~min}$. The pellet was washed three times with ice-cold Hank's balanced salt solution and finally resuspended in DMEM/Ham's Nutrient Mixture F12, supplemented with $10 \%$ FBS, insulin-transferrin-selenium, hydrocortisone and antibiotics. The final cell suspension was then plated onto coverslips coated with type IV collagen. All experiments were ethically approved by the Swedish Ethical Committee North, numbers 183/03 (rat) and 03-143 (human).

\section{Reagents}

Reagents and concentrations were as follows: ouabain $(1 \mu \mathrm{M}$ for hPT cells and $100 \mu \mathrm{M}$ for rPT cells since rodents are more resistant to ouabain than humans [12], Sigma-Aldrich), ATP (25 $\mu \mathrm{M}$, Sigma-Aldrich), bradykinin (20 nM, Sigma-Aldrich), ionomycin (1 $\mu \mathrm{M}$, Sigma-Aldrich), thapsigargin (1 $\mu \mathrm{M}$, Sigma-Aldrich), bis (2-aminophenoxy)ethane tetraacetic acid (BAPTA, 10 $\mu \mathrm{M}$, Molecular Probes), 2-aminoethoxydiphenyl borate (2-APB, $100 \mu \mathrm{M}$, Sigma-Aldrich), KN-93 (10 $\mu \mathrm{M}$, SigmaAldrich), LY294002 (10 $\mu \mathrm{M}$, Sigma-Aldrich), wortmanin (5 $\mu \mathrm{M}$, Sigma-Aldrich), FK506 (20 nM, Sigma-Aldrich), Go6983 (1 $\mu \mathrm{M}$, Sigma-Aldrich), calphostin (5 $\mu \mathrm{M}$, Sigma-Aldrich), and cycloheximide (CHX, $100 \mu \mathrm{M}$, Sigma-Aldrich). Cells were treated with inducers of $\mathrm{Ca}^{2+}$ signaling (ouabain, ATP, bradykinin) $3 \mathrm{~h}$ prior immunostaining and with inhibitors $15 \mathrm{~min}$ prior $\mathrm{Ca}^{2+}$ signalinginducers.

\section{Immunocytochemistry}

Immunocytochemistry of PC2 in hPT and rPT cells was performed according to standard protocol. Cells were fixed with $4 \%$ paraformaldehyde for $15 \mathrm{~min}$ and then permeabilized for 10 min with $0.3 \%$ Triton X-100. After blocking with $1 \%$ BSA for $1 \mathrm{~h}$, cells were incubated overnight at $4{ }^{\circ} \mathrm{C}$ with anti-PC2 polyclonal antibodies (generously provided by Dr. Stefan Somlo, Department of Internal Medicine, Yale University School of Medicine, New Haven, CT, USA and Dr. Jing Zhou, Renal Division, Department of Medicine, Brigham and Women's Hospital and Harvard Medical School, Boston, MA, USA) against amino acids 103 to 203 (YCB9) [13] or amino acids 44 to 62 [7] on the N-terminus, respectively. Both antibodies showed similar PC2 pattern in proximal tubule cells (Additional file 1: Figure S1). All images presented here are using the antibody against YCB9. Cells were incubated for $1 \mathrm{~h}$ at room temperature with Alexa488 fluorescent secondary antibody (1:500, Molecular Probes). Staining with only secondary antibody was used as control (Additional file 2: Figure S2). Slides were scanned with similar exposure time using a Leica TCS SP inverted confocal laser scanning microscope equipped with a 40x/1.4 NA oil-immersion objective.

\section{Calcium imaging}

For $\mathrm{Ca}^{2+}$ experiments cells were loaded with $5 \mu \mathrm{M}$ Fura2/AM (Invitrogen) at $37^{\circ} \mathrm{C}$ for $1 \mathrm{~h}$. Calcium measurements were performed at $37^{\circ} \mathrm{C}$ in a heated chamber (QE-1, Warner Instruments) with a cooled CCD camera (ORCA-ERG, Hamamatsu) mounted on an upright microscope (Axioskop 2 FS, Zeiss) equipped with a 40x/0.8 NA water dipping lens. Excitation at 340 and $380 \mathrm{~nm}$ was carried out with a monochromator (Polychrome IV, TILL Photonics). Devices were 
controlled and data were recorded and analyzed with the computer software MetaFluor (Molecular Devices). All experiments were performed in physiological buffer (100 mM NaCl, $4 \mathrm{mM} \mathrm{KCl,} 25 \mathrm{mM} \mathrm{NaHCO} 3,1.5 \mathrm{mM}$ $\mathrm{CaCl}_{2}, 1.1 \mathrm{mM} \mathrm{MgCl}, 1 \mathrm{mM} \mathrm{NaH} \mathrm{PO}_{4}, 10 \mathrm{mM}$ D-glucose, and $20 \mathrm{mM}$ HEPES, pH 7.4). An oscillating cell was defined as a cell that displayed two or more $\mathrm{Ca}^{2+}$ peaks, of which each peak's amplitude was at least $10 \%$ over baseline. PM permeability was measured using the Fura-2 fluorescence quenching technique with $\mathrm{Mn}^{2+}$. Fura-2 was then excited at the $\mathrm{Ca}^{2+}$-dependent wavelength, $340 \mathrm{~nm}$, and at the $\mathrm{Ca}^{2+}$-independent wavelength, $360 \mathrm{~nm}$. The $\mathrm{PM} \mathrm{Ca}{ }^{2+}$ permeability was measured as the fluorescence decrease after adding $0.1 \mathrm{mM} \mathrm{MnC} 1_{2}$ to the recording medium.

\section{Statistics}

PM PC2-positive cells were counted and expressed as the percentage over the total number of cells. The percentage of PM-positive cells corresponding to the control condition was assigned a value of 1 , and the different treatments were normalized over this value in order to express them as fold-values over control. Data are presented as mean \pm SEM or as a representative result of at least three independent experiments. One-way ANOVA with a Bonferroni post hoc test was used and significance was accepted at $P<0.05$.

\section{Results}

Subcellular localization of PC2 is dynamically regulated The subcellular localization of the PC2 protein was studied using immunocytochemistry in human primary proximal tubule (hPT) cells prepared from nephrectomy patients, as described in Materials and methods. In un-stimulated hPT cells PC2 exhibited a cytoplasmic/ reticular staining (Figure 1A), in good agreement with a previous report [3]. Plotting the localization profile along a line through an individual cell confirmed the cytoplasmic/reticular localization pattern (Figure 1B). To test the dynamic nature of PC2 localization, hPT cells were challenged with the steroid ouabain, known to induce intracellular $\mathrm{Ca}^{2+}$ oscillations in rat kidney cells $[14,15]$. When hPT cells were exposed to ouabain, a strong PC2 localization in the PM was observed (Figure $1 \mathrm{C}$ and $\mathrm{D})$. To test whether this effect was due to an increase of cytosolic $\mathrm{Ca}^{2+}, \mathrm{hPT}$ cells were treated with nucleotide adenosine triphosphate (ATP), a well-established inducer of cytosolic $\mathrm{Ca}^{2+}$ signaling in renal cells [16]. hPT cells exposed to ATP exhibited a clear translocation of PC2 towards the PM (Figure 1E and F). Quantification analysis of $n$ single-cells from $N$ independent preparations showed that the number of hPT cells positive for PC2 in the PM was significantly increased $5.3 \pm 1.0$-fold by
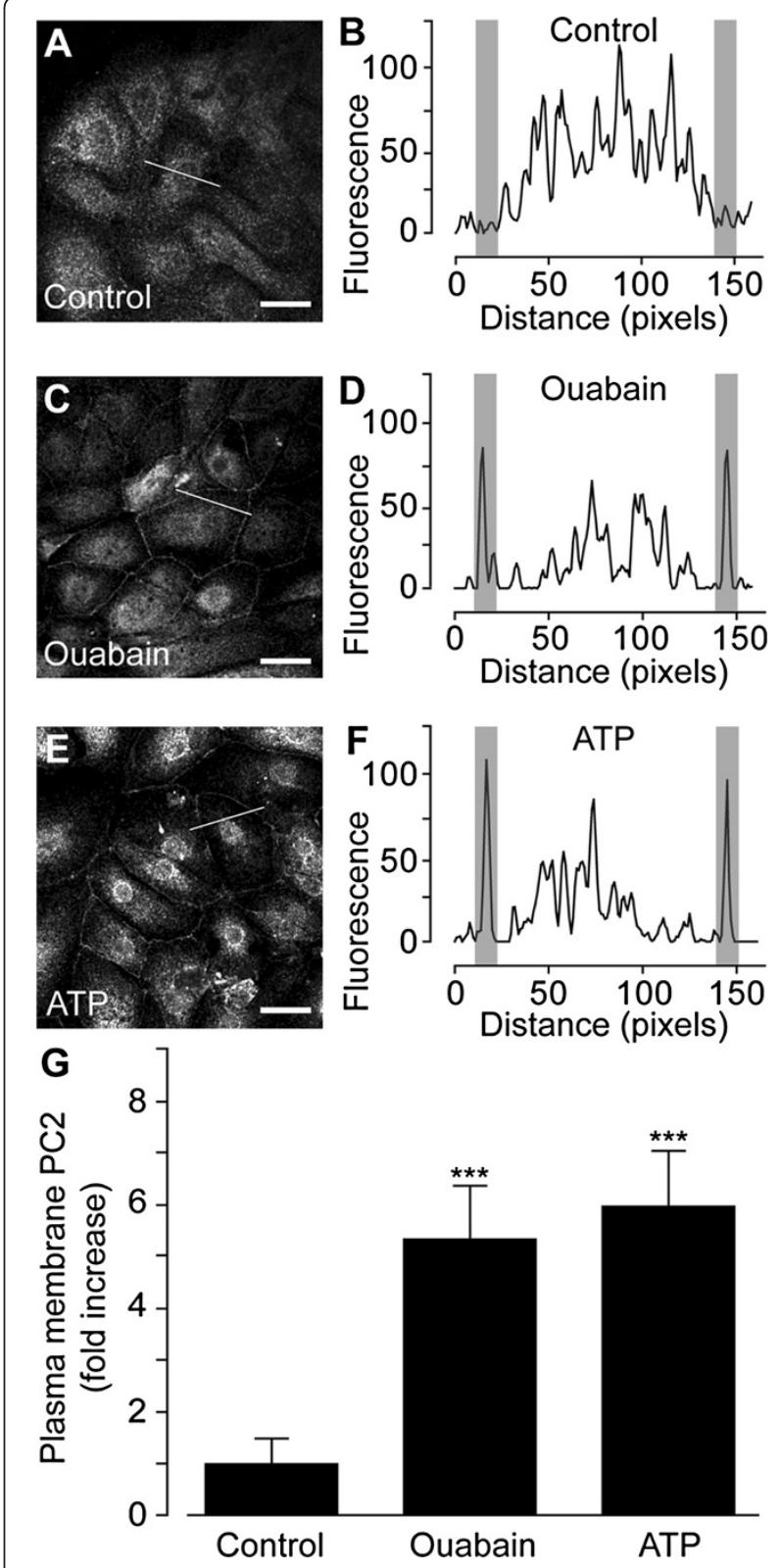

Figure $1 \mathrm{PC} 2$ trafficking to the PM in human proximal tubule (hPT) cells. (A-F). Immunocytochemistry of PC2 in hRT cells treated with control (A), $1 \mu \mathrm{M}$ ouabain (C), or $25 \mu \mathrm{M}$ ATP (E). Scale bars, 20 $\mu \mathrm{m}$. Localization profile of PC2 along a line (as indicated) through the center of a single hPT cell treated with control (B), ouabain (D), or ATP (F). Gray areas represent PM regions. (G) Quantitative analysis of a number of PM PC2-positive hRT cells following indicated treatments. Values are the mean \pm SEM, and ${ }^{* * *} P<0.001$ vs. control.

ouabain and $6.0 \pm 1.1$-fold by ATP (control $n=76 N=6$, ouabain $n=159 N=7$, ATP $n=70 N=4$ ) (Figure 1G).

Next, the dynamic localization pattern of PC2 in rat kidney cells was investigated. Immunocytochemistry experiments in primary cultures of rat proximal tubule (rPT) cells showed a cytoplasmic/reticular localization pattern of PC2 in un-stimulated cells (Figure 2A and B), 

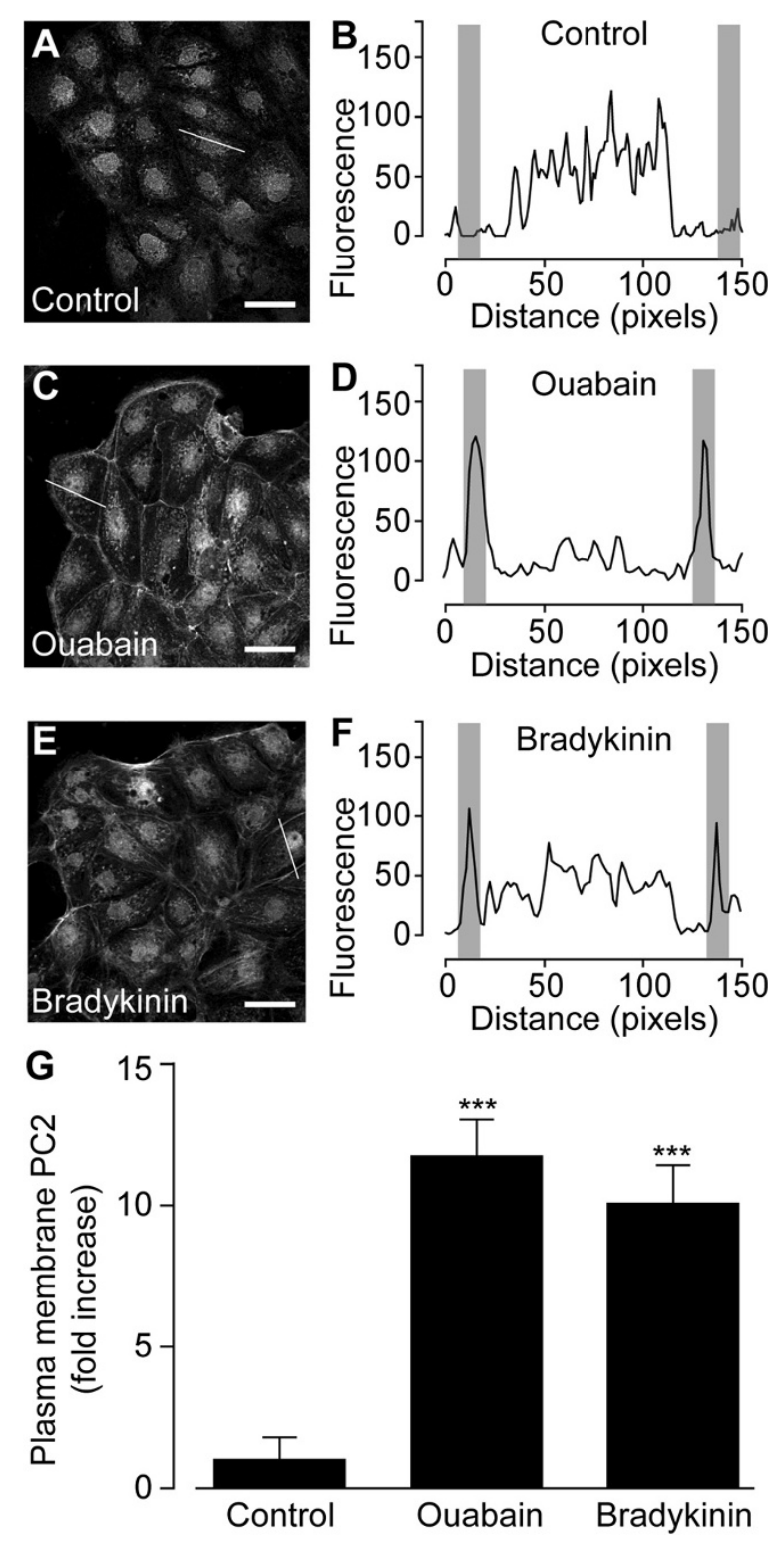

Figure $2 \mathrm{PC} 2$ trafficking to the PM in rat proximal tubule (rPT) cells. (A-F) Immunocytochemistry of PC2 in $\mathrm{rPT}$ cells treated with control (A), $100 \mu \mathrm{M}$ ouabain (C), or $20 \mathrm{nM}$ bradykinin (E). Scale bars, $20 \mu \mathrm{m}$. Localization profile of PC along a line (as indicated) through the center of a single rPT cell treated with control (B), ouabain (D), or bradykinin (F). Gray areas represent PM regions. (G) Quantitative analysis of a number of PM PC2 positive rPT cells following indicated treatments. Values are the mean \pm SEM and ${ }^{* * *} P<0.001$ vs. control.

in accordance with results from hPT cells. This basal PC2 localization was clearly translocated towards the PM when rPT cells were treated with ouabain (Figure 2C and D) or bradykinin (Figure 2E and F). Both ouabain and bradykinin are reported to induce a $\mathrm{Ca}^{2+}$ response in $\mathrm{rPT}$ cells [15]. Quantitative analysis showed that the number of rPT cells positive for PC2 in the PM was significantly increased $11.7 \pm 2.1$-fold by ouabain and $10.1 \pm 2.2$-fold by bradykinin (control $n=175 N=8$, ouabain $n=123 N=7$, bradykinin $n=104 N=5$ ) (Figure 2G).

To test whether an increase of the cytosolic $\mathrm{Ca}^{2+}$ concentration was sufficient to induce PC2-trafficking towards the PM, rPT cells were exposed to various wellknown agents affecting the cellular $\mathrm{Ca}^{2+}$ machinery. First, a $\mathrm{Ca}^{2+}$ influx was induced by using the $\mathrm{Ca}^{2+}$ ionophore ionomycin. Ionomycin caused a significant $10.1 \pm$ 0.6-fold increase of PC2 PM positive rPT cells (control $n=175 N=8$, ionomycin $n=139 N=8$ ) (Figure 3A). In another approach, a transient $\mathrm{Ca}^{2+}$ release from the ER was induced by using thapsigargin, an inhibitor of the sarcoplasmic/endoplasmic reticulum $\mathrm{Ca}^{2+}$ ATPase, which caused a raise in cytosolic $\mathrm{Ca}^{2+}$. Thapsigargin stimulated a significant $6.4 \pm 1.3$-fold increase of PC2 translocation to the PM in rPT cells (thapsigargin $n=73$ $N=6$ ) (Figure 3B). The stimulatory effect of thapsigargin on PC2 trafficking was $1.9 \pm 1.0$-fold and reversed in cells pre-incubated with BAPTA (thapsigargin + BAPTA $n=76 \mathrm{~N}=7$ ), an intracellular $\mathrm{Ca}^{2+}$ chelator (Figure $3 \mathrm{~B}$ ).

Taken together, these results demonstrate that cytosolic $\mathrm{Ca}^{2+}$ regulates PC2 trafficking in both human and rat kidney cells.

\section{$\mathrm{Ca}^{2+}$ channels in the PM are more abundant in $\mathrm{Ca}^{2+}$ oscillating cells}

A functional study of the $\mathrm{PM} \mathrm{Ca}^{2+}$ permeability was then conducted using the manganese $\left(\mathrm{Mn}^{2+}\right)$ quenching technique, based on the higher affinity Fura- 2 has for $\mathrm{Mn}^{2+}$ than for $\mathrm{Ca}^{2+}$. When $\mathrm{Mn}^{2+}$ binds to Fura-2, it displaces $\mathrm{Ca}^{2+}$, resulting in a decreased fluorescence emission signal. Fura-2 preloaded rPT cells were first treated with ouabain and monitored using time-lapse $\mathrm{Ca}^{2+}$ imaging. Subsequent addition of $\mathrm{Mn}^{2+}$ to the recording medium induced a rapid decrease in the Fura-2 emission signal (Figure $3 \mathrm{C}$ ). Interestingly, cells that were responding to ouabain with cytosolic $\mathrm{Ca}^{2+}$ oscillations showed a significantly steeper decrease in Fura-2 fluorescence compared to that of nonoscillating cells (Figure 3D). These results indicate an increased amount of $\mathrm{Ca}^{2+}$ channels present in the PM of cells exhibiting ouabain-induced $\mathrm{Ca}^{2+}$ oscillations.

\section{Dynamic localization of PC2 is regulated by cytosolic $\mathrm{Ca}^{2+}$} signaling

To further investigate the contribution of cytosolic $\mathrm{Ca}^{2+}$ signaling on PC2-trafficking, immunocytochemistry experiments were conducted on rPT cells stimulated with ouabain in the presence of intracellular $\mathrm{Ca}^{2+}$ signaling inhibitors. First, the $\mathrm{Ins}_{3} \mathrm{R}$ pathway was inhibited using 2-APB. In the absence of 2-APB, ouabain caused a significant $11.7 \pm 1$.3-fold increase of PC2 translocation to the PM (control $n=175 N=8$, ouabain $n=74 N=4$ ), while pre-incubation with 2-APB 

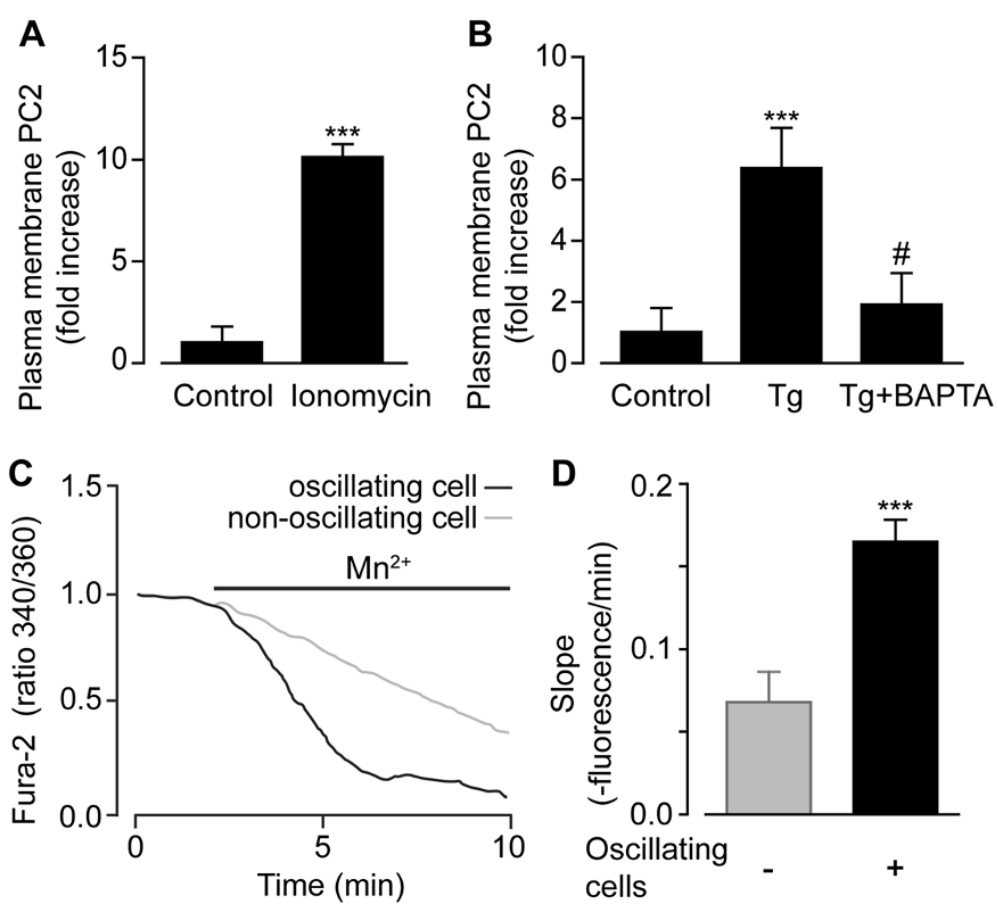

Figure 3 Intracellular $\mathrm{Ca}^{2+}$ release mediates PC2 translocation to the PM. (A-B) Quantitative analysis of a number of PM PC2-positive rPT cells following treatment with $1 \mu \mathrm{M}$ ionomycin (A), $1 \mu \mathrm{M}$ thapsigargin (Tg) (B), or thapsigargin with $10 \mu \mathrm{M}$ BAPTA (B). (C) Single cell Ca ${ }^{2+}$ recording of two rPT cells loaded with Fura-2/AM treated with $100 \mu \mathrm{M}$ ouabain followed by sequential addition of $2 \mathrm{mM} \mathrm{Mn}^{2+}$ to the recoding medium. (D) Statistical analysis of slope decrease in non-oscillating (gray bar) and oscillating cells (black bar) in response to ouabain after $\mathrm{Mn}^{2+}$ addition to the recording medium. Values are the mean $\pm S E M,{ }^{*} P<0.05$, ${ }^{* *} P<0.001$ vs. control, and $\# P<0.001$ vs. treatment.

caused a significant $4.3 \pm 1.5$-fold decrease of ouabaininduced PC2 PM trafficking (ouabain $n=123 \quad N=7$, ouabain +2 -APB $n=94 N=4$ ) (Figure 4A). Next, cytosolic $\mathrm{Ca}^{2+}$ was buffered using BAPTA. This treatment completely blocked the PC2 trafficking to the PM induced by ouabain ( $0.8 \pm 0.7$-fold, ouabain $n=123 N=7$, ouabain + BAPTA $n=56 N=4$ ) (Figure 4B). Together, these results suggest a pivotal role of $\operatorname{Ins}_{3} \mathrm{R}$ in triggering cytosolic $\mathrm{Ca}^{2+}$-dependent $\mathrm{PC} 2$ trafficking.

\section{$\mathrm{Ca}^{2+}$-dependent protein kinases are involved in dynamic PC2 localization}

To investigate the involvement of $\mathrm{Ca}^{2+}$-sensitive kinases on PC2 trafficking, selective chemical inhibitors were used. Under control conditions, ouabain induced a significant $12.4 \pm 1.3$-fold translocation of $\mathrm{PC} 2$ to the $\mathrm{PM}$ (ouabain $n=114 N=5$ ) (Figure 4C). A common target for $\mathrm{Ca}^{2+}$ signaling in mammalian cells is $\mathrm{Ca}^{2+} /$ Calmodulindependent kinase (CaMK). Selective inhibition of CaMK with KN93 completely blocked the ouabain-induced PC2 trafficking to the PM $(1.2 \pm 0.9$-fold, ouabain + KN93 $n=104 N=7$ ) (Figure $4 C$ ). The contribution of the Phosphatidylinositol 3-kinase (PI3K)/Akt pathway was next investigated. Pre-incubation with LY294002 or wortmanin also produced a significant decrease in ouabain-induced PC2 translocation (6.9 \pm 1.5 -fold, ouabain + LY294002 $n=72 N=4$ and $4.8 \pm 1.4$-fold, ouabain + wortmanin $n=92$ $N=4$, respectively) (Figure $4 \mathrm{C}$ ). Inhibition of protein kinase $\mathrm{C}$ (PKC) by means of broad spectrum PKC inhibitors Go6983 or calphostin resulted in decreased levels of PC2 staining in the PM that reached statistical significance only in Go6983 pre-treated cells $(8.4 \pm 1.0$-fold, ouabain + Go6983 $n=117 N=6$ and 9.9 \pm 1.7 -fold, ouabain + calphostin $n=67 N=3$ ) (Figure 4C). Finally, inhibition of the $\mathrm{Ca}^{2+}$-dependent protein-phosphatase calcineurin with FK506, had no effect on the PC2 translocation (11.4 \pm 1.0 -fold, ouabain + FK506 $n=124 N=7$ ) (Figure 4C).

The observed increase in the PC2 immunosignal from the PM could be due to di novo synthesis of PC2 proteins. To investigate this hypothesis, cells were pre-treated with cycloheximide $(\mathrm{CHX})$ to stop the translation of new proteins. Pre-treatment of cells with CHX failed to stop increased PC2 trafficking to the PM following ouabain treatment (11.4 \pm 0.8 -fold, ouabain + CHX $n=51 N=3$ ) (Figure 4C).

Together, these results suggest a translocation of cellular PC2 to the PM via the intracellular $\mathrm{Ca}^{2+} / \mathrm{CaMK}$ pathway, with some involvement of the PI3K/Akt and PKC pathways. 

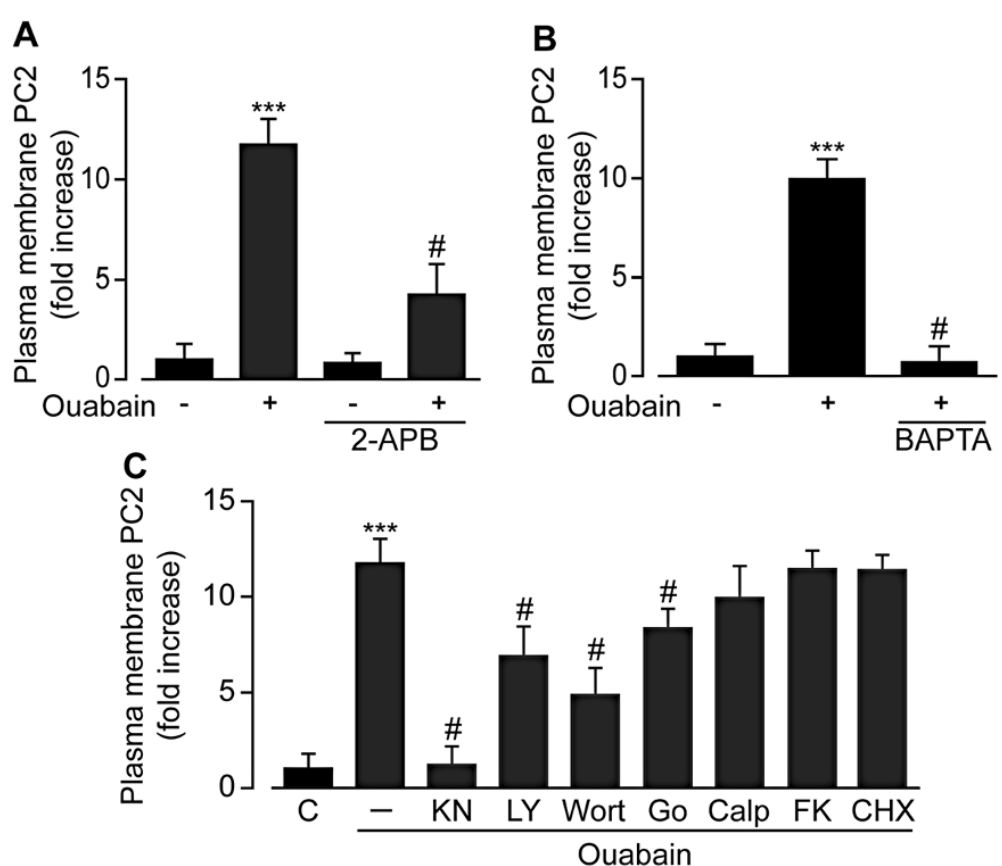

Figure 4 PC2 trafficking to the PM depends on intracellular $\mathrm{Ca}^{2+}$ signaling and $\mathrm{Ca}^{2+}$-dependent kinases. (A-B) Quantitative analysis of PM

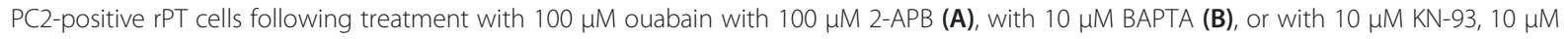
LY294002, $5 \mu \mathrm{M}$ wortmanin, $20 \mathrm{nM}$ FK506, $1 \mu \mathrm{M}$ Go6983, $5 \mu \mathrm{M}$ calphostin, or $100 \mu \mathrm{M}$ cycloheximide (C). Values are the mean \pm SEM, ${ }^{* * * P}<0.001$ vs. control, and $\# P<0.001$ vs. treatment.

\section{Discussion}

The notion that polycystin proteins act as cellular sensors that can modulate intracellular $\mathrm{Ca}^{2+}$ signaling is now well established [3]. Mounting evidence also supports the idea that mutations in the $\mathrm{PC} 1$ or $\mathrm{PC} 2$ gene perturb proper assembly, activity, and regulation of the polycystin proteins. Intriguingly, $\mathrm{PC} 2$ loss-of-function in modulating intracellular $\mathrm{Ca}^{2+}$ concentration may provide a possible explanation for the pathophysiology of ADPKD [17]. Here, we showed that the PC2 subcellular localization pattern is dynamically regulated in both human and rat kidney cells. Dependent on cytosolic $\mathrm{Ca}^{2+}$ increases, PC2 translocated from the cytosolic/ER compartment to the PM. When cells were challenged with ouabain, a treatment that has been shown to induce Ins $P_{3} \mathrm{R}$-dependent $\mathrm{Ca}^{2+}$ oscillations in kidney cells $[14,15]$, an increased PM PC2 localization and PM Ca ${ }^{2+}$ permeability were observed. The $\mathrm{PM} \mathrm{Ca}^{2+}$ permeability was indirectly examined using $\mathrm{Mn}^{2+}$ quenching and electrophysiology recordings are required to determine absolute numbers. Pharmacological inhibition of key intracellular $\mathrm{Ca}^{2+}$ release components suppressed $\mathrm{Ca}^{2+}$-mediated PC2 trafficking, indicating a $\mathrm{Ca}^{2+}$-dependent translocation process. CaMK, a canonic $\mathrm{Ca}^{2+}$-activated kinase, was necessary for PC2 translocation, whereas the PI3K or PKC kinases contributed to a lesser extent. Mutations causing ADPKD have been reported altering the sub-cellular PC2 localization and/or function. For example, PC2 having the naturally occurring pathogenic mutant $\mathrm{R} 742 \mathrm{X}$ resides in the PM [13], however, without having channel activity [18]. Another pathogenic missense mutation of PC2 is D511V [19], where a single amino acid in the third membrane-spanning domain is mutated, results in a loss of PC2 channel activity [3].

The subcellular localization pattern of the PC2 protein has been a long-lasting matter of controversy [20]. In various cell lines (LLCPK1, MDCK, HEK-293) and adult human kidney $\mathrm{PC} 2$ has been detected in ER where it function as a $\mathrm{Ca}^{2+}$ channel $[13,21]$. PC2 has also been detected in the basolateral and lateral cell membrane in adult human and rat kidney cells and collecting duct cells where it functions as cell-cell adhesion [6,21-25]. In primary cilium of human proximal tubule and mouse collecting duct cells PC2 is reported as a flow-sensitive channel $[7,26,27]$. These observations, and many others that report different PC2 localization [20], support the idea of a dynamic protein with its expression regulated by sub-cellular mechanisms. For example, PC2 contains an ER retention signal in its $\mathrm{C}$-terminal sequence that inhibits trafficking to the cell surface [28]. PC2 deletion mutants for this ER retention signal constitutively translocate to the PM [18]. In ER $\mathrm{Ca}^{2+}$ stores, PC2 acts as a $\mathrm{Ca}^{2+}$-release channel that amplifies $\mathrm{Ca}^{2+}$ transients initiated by $\mathrm{InsP}_{3} \mathrm{Rs}[3] . \mathrm{Ca}^{2+}$ releasing activity of $\mathrm{PC} 2$ is regulated by $\mathrm{Ca}^{2+}$ itself through a $\mathrm{Ca}^{2+}$-induced $\mathrm{Ca}^{2+}$ release mechanism [29] that requires direct association 
with $\operatorname{Ins}_{3} \mathrm{R}$ and regulates the physiological level of the intracellular $\mathrm{Ca}^{2+}$ concentration [30].

PC2 has previously been reported to be present in the PM $[22,25]$. PC2 localization to the PM is then modulated by chemical chaperones, proteasome inhibitors, protein-protein interactions and phosphorylation, and also upon massive overexpression that eventually overrides the ER retention machinery [6]. Under certain conditions, for example when PC2 is truncated at or before Glu787 its product is detected in the PM [13]. Trafficking of PC2 in cells has also been suggested to occur through its physical interaction with $\mathrm{PC} 1$ via their C-termini, forming a heteromeric, non-selective cationic channel complex [31]. Efficient assembly of PC1 and PC2 appears to be essential for proper trafficking and channel activity [32]. These previous results and the findings presented here support the idea of a dynamically regulated subcellular localization of $\mathrm{PC} 2$.

Our results indicate that CaMK is an important regulator of PC2 trafficking to the PM. Indeed, phosphorylation has previously been demonstrated in PC2 trafficking [13]. Two evolutionarily conserved phosphorylation sites in the $\mathrm{PC} 2$ protein sequence were suggested to control its subcellular localization: serine residue 76 (Ser76)/Ser80 and Ser812, which are phosphorylated by glycogen synthase kinase 3 (GSK3) [33] and casein kinase 2 (CK-2) [34], respectively. We speculate that the PM PC2 portion might be phosphorylated differently than ER PC2. It has been shown that PKC-dependent phosphorylation at Ser801 is essential for a normal function of $\mathrm{PC} 2$ as an ER $\mathrm{Ca}^{2+}$ release channel [35]. Additionally, Never in mitosis A-related kinase 8 (Nek8), a serine/threonine kinase that is mutated in some cases of juvenile polycystic kidney disease, induced abnormal PC2 phosphorylation and trafficking to primary cilia in the kidney [36]. The $\mathrm{Ca}^{2+}$ dependent trafficking of PC2 reported herein might also play a role in the PC2 expression profile in cilia. Surprisingly little is known about the upstream physiological stimuli activating all these kinases to critically regulate $\mathrm{PC} 2$ trafficking. Whether the $\mathrm{Ca}^{2+}$ signaling pathway presented here is the missing upstream link in controlling CaMK, GSK-3, CK-2 or Nek8 in PC2 trafficking remains to be further examined.

Polycystin proteins are expressed in primary cilia of cultured renal epithelial cells, where they might function in transducing sensory information, such as shear stress during fluid flow [7], leading to $\mathrm{Ca}^{2+}$ influx through mechanically sensitive channels that reside in the ciliary membrane [37]. This $\mathrm{Ca}^{2+}$ signal is then amplified by $\mathrm{Ca}^{2+}$ release from internal ER/SR stores and spreads to neighboring cells through gap junctions. PC2 has been suggested to be a mechano-sensitive channel since mechano-transduction is abolished in the presence of a specific PC2 blocking antibody [7] and in epithelial cells isolated from PC1-deficient mice [7]. Intracellular $\mathrm{Ca}^{2+}$ release and PC2 trafficking to the PM may form a positive loop for $\mathrm{Ca}^{2+}$ influx and intracellular $\mathrm{Ca}^{2+}$ overload, a condition that has been reported previously in ADPKD progression [1,5]. However, the exact contribution of PC2 dynamic localization to the PM in ADPKD pathogenesis remains to be elucidated.

Our results show that endogenous agonists that increase cytosolic $\mathrm{Ca}^{2+}$ levels, such as ouabain, ATP, or bradykinin, induced $\mathrm{PC} 2$ trafficking to the $\mathrm{PM}$. It was previously reported that ouabain triggers $\operatorname{Ins}_{3} \mathrm{R}$ dependent intracellular $\mathrm{Ca}^{2+}$ oscillation in cultured rPT cells $[14,15]$. According to the results presented here, cells that exhibited ouabain-induced $\mathrm{Ca}^{2+}$ oscillations had increased $\mathrm{PM} \mathrm{Ca}^{2+}$ permeability. Other reports have shown that cilia mechano-activation leads to ATP secretion, which acts as an auto/paracrine signal through purinergic receptor activation and intracellular $\mathrm{Ca}^{2+}$ signals [38], suggesting that both agonists may contribute to PC2 translocation to the PM under physiopathological conditions.

\section{Conclusion}

We conclude that PC2 subcellular localization is dynamically regulated through an intracellular $\mathrm{Ca}^{2+}$-dependent pathway, which in turn could be related to cystogenesis and ADPKD pathogenesis.

\section{Additional files}

Additional file 1: Figure S1. PC2 expression pattern in proximal tubule cells using two different antibodies. (A-D) Immunocytochemistry of PC2 in rat proximal tubule cells treated with control $(A, C)$ or $100 \mu \mathrm{M}$ ouabain $(B, D)$ using anti-PC2 polyclonal antibodies against amino acids 103 to 203 (YCB9) or 44 to 62 on the N-terminus. Scale bars, $20 \mu \mathrm{m}$.

Additional file 2: Figure S2. Immunocytochemistry negative control without primary PC2 antibody. (A-B) Immunocytochemistry staining in rat proximal tubule cells without (A) and with (B) anti-PC2 antibody present. Scale bars, $20 \mu \mathrm{m}$.

\section{Competing interests}

The authors declare that they have no competing interests.

\section{Authors' contributions}

AM conceived the study and participated in its design, carried out the immunocytochemistry studies, cultured cells and drafted the manuscript. Cl performed the statistical analysis and drafted the manuscript. SM carried out the manganese quenching experiments. AA conceived the study and participated in its design. PW participated in the design of the study and coordinated the collection of human tissue. PU designed the study and wrote the manuscript. All authors read and approved the final manuscript.

\section{Acknowledgments}

This study was supported by the Swedish Research Council, Åke Wibergs Stiftelse, Jeanssons Stiftelser, Magnus Bergvalls Stiftelse, the University of the Ryukyus Faculty of Medicine, Okinawa, Japan, the Japan Science and Technology Agency, and the Ministry of Education, Science, Sports, Culture, and Technology of Japan. 


\section{Author details}

${ }^{1}$ Department of Medical Biochemistry and Biophysics, Karolinska Institutet, Stockholm SE-171 77, Sweden. ${ }^{2}$ Department of Molecular Medicine and Surgery, Karolinska University Hospital, Stockholm SE-171 76, Sweden. 3 Department of Woman and Child Health, Astrid Lindgren Children's Hospital Q2:09, Karolinska University Hospital, Stockholm SE-171 76, Sweden.

Received: 6 September 2012 Accepted: 6 February 2013

Published: 11 February 2013

\section{References}

1. Harris PC: Molecular basis of polycystic kidney disease: PKD1, PKD2 and PKHD1. Curr Opin Nephrol Hypertens 2002, 11(3):309-314.

2. Harris PC, Torres VE: Polycystic kidney disease. Annu Rev Med 2009, 60:321-337.

3. Koulen P, Cai Y, Geng L, Maeda Y, Nishimura S, Witzgall R, Ehrlich BE, Somlo S: Polycystin-2 is an intracellular calcium release channel. Nat Cell Biol 2002, 4(3):191-197.

4. Anyatonwu Gl, Ehrlich BE: Calcium signaling and polycystin-2. Biochem Biophys Res Commun 2004, 322(4):1364-1373.

5. Gonzalez-Perrett S, Kim K, Ibarra C, Damiano AE, Zotta E, Batelli M, Harris PC, Reisin IL, Arnaout MA, Cantiello HF: Polycystin-2, the protein mutated in autosomal dominant polycystic kidney disease (ADPKD), is a Ca2 + -permeable nonselective cation channel. Proc Natl Acad Sci U S A 2001, 98(3):1182-1187.

6. Luo Y, Vassilev PM, Li X, Kawanabe Y, Zhou J: Native polycystin 2 functions as a plasma membrane $\mathrm{Ca} 2+-$ permeable cation channel in renal epithelia. Mol Cell Biol 2003, 23(7):2600-2607.

7. Nauli SM, Alenghat FJ, Luo Y, Williams E, Vassilev P, Li X, Elia AE, Lu W, Brown EM, Quinn SJ, et al: Polycystins 1 and 2 mediate mechanosensation in the primary cilium of kidney cells. Nat Genet 2003 33(2):129-137.

8. Clapham DE: Calcium signaling. Cell 2007, 131(6):1047-1058.

9. Uhlen P, Fritz N: Biochemistry of calcium oscillations. Biochem Biophys Res Commun 2010, 396(1):28-32

10. Abdul-Majeed S, Nauli SM: Calcium-mediated mechanisms of cystic expansion. Biochim Biophys Acta 1812, 10:1281-1290.

11. Uhlen P, Laestadius A, Jahnukainen T, Soderblom T, Backhed F, Celsi G, Brismar H, Normark S, Aperia A, Richter-Dahlfors A: Alpha-haemolysin of uropathogenic E. coli induces Ca2+ oscillations in renal epithelial cells. Nature 2000, 405(6787):694-697.

12. Kaplan JH: Biochemistry of Na, K-ATPase. Annu Rev Biochem 2002, 71:511-535

13. Cai Y, Maeda Y, Cedzich A, Torres VE, Wu G, Hayashi T, Mochizuki T, Park JH, Witzgall R, Somlo S: Identification and characterization of polycystin-2, the PKD2 gene product. J Biol Chem 1999, 274(40):28557-28565.

14. Aizman $\mathrm{O}$, Uhlen $\mathrm{P}$, Lal M, Brismar $\mathrm{H}$, Aperia A: Ouabain, a steroid hormone that signals with slow calcium oscillations. Proc Natl Acad Sci U S A 2001, 98(23):13420-13424.

15. Miyakawa-Naito A, Uhlen P, Lal M, Aizman O, Mikoshiba K, Brismar H, Zelenin S, Aperia A: Cell signaling microdomain with Na,K-ATPase and inositol 1,4,5-trisphosphate receptor generates calcium oscillations. J Biol Chem 2003, 278(50):50355-50361.

16. Unwin RJ, Bailey MA, Burnstock G: Purinergic signaling along the renal tubule: the current state of play. News Physiol Sci 2003, 18:237-241.

17. Stayner C, Zhou J: Polycystin channels and kidney disease. Trends Pharmacol Sci 2001, 22(11):543-546.

18. Chen XZ, Segal Y, Basora N, Guo L, Peng JB, Babakhanlou H, Vassilev PM, Brown EM, Hediger MA, Zhou J: Transport function of the naturally occurring pathogenic polycystin-2 mutant, R742X. Biochem Biophys Res Commun 2001, 282(5):1251-1256.

19. Reynolds DM, Hayashi T, Cai Y, Veldhuisen B, Watnick TJ, Lens XM Mochizuki T, Qian F, Maeda Y, Li L, et al: Aberrant splicing in the PKD2 gene as a cause of polycystic kidney disease. J Am Soc Nephrol 1999, 10(11):2342-2351.

20. Ong AC, Harris PC: Molecular pathogenesis of ADPKD: the polycystin complex gets complex. Kidney Int 2005, 67(4):1234-1247.

21. Newby LJ, Streets AJ, Zhao Y, Harris PC, Ward CJ, Ong AC: Identification, characterization, and localization of a novel kidney polycystin1-polycystin-2 complex. J Biol Chem 2002, 277(23):20763-20773.
22. Foggensteiner L, Bevan AP, Thomas R, Coleman N, Boulter C, Bradley J, Ibraghimov-Beskrovnaya O, Klinger K, Sandford R: Cellular and subcellular distribution of polycystin-2, the protein product of the PKD2 gene. J Am Soc Nephrol 2000, 11(5):814-827.

23. Obermuller N, Gallagher AR, Cai Y, Gassler N, Gretz N, Somlo S, Witzgall R: The rat pkd2 protein assumes distinct subcellular distributions in different organs. Am J Physiol 1999, 277(6 Pt 2):F914-F925.

24. Ong AC, Wagner B: Detection of proximal tubular motile cilia in a patient with renal sarcoidosis associated with hypercalcemia. Am J Kidney Dis 2005, 45(6):1096-1099.

25. Scheffers MS, Le H, van der Bent P, Leonhard W, Prins F, Spruit L, Breuning $\mathrm{MH}$, de Heer $\mathrm{E}$, Peters DJ: Distinct subcellular expression of endogenous polycystin-2 in the plasma membrane and Golgi apparatus of MDCK cells. Hum Mol Genet 2002, 11(1):59-67.

26. Pazour GJ, San Agustin JT, Follit JA, Rosenbaum JL, Witman GB: Polycystin-2 localizes to kidney cilia and the ciliary level is elevated in orpk mice with polycystic kidney disease. Current biology: CB 2002, 12(11):R378-R380.

27. Yoder BK, Hou X, Guay-Woodford LM: The polycystic kidney disease proteins, polycystin-1, polycystin-2, polaris, and cystin, are co-localized in renal cilia. J Am Soc Nephrol 2002, 13(10):2508-2516.

28. Delmas P, Nauli SM, Li X, Coste B, Osorio N, Crest M, Brown DA, Zhou J: Gating of the polycystin ion channel signaling complex in neurons and kidney cells. FASEB J 2004, 18(6):740-742.

29. Petri ET, Celic A, Kennedy SD, Ehrlich BE, Boggon TJ, Hodsdon ME: Structure of the EF-hand domain of polycystin-2 suggests a mechanism for Ca2 + -dependent regulation of polycystin-2 channel activity. Proc Natl Acad Sci U S A 2010, 107(20):9176-9181.

30. Sammels E, Devogelaere B, Mekahli D, Bultynck G, Missiaen L, Parys JB, Cai Y, Somlo S, De Smedt H: Polycystin-2 activation by inositol 1,4,5trisphosphate-induced $\mathrm{Ca} 2+$ release requires its direct association with the inositol 1,4,5-trisphosphate receptor in a signaling microdomain. J Biol Chem 2010, 285(24):18794-18805.

31. Vassilev PM, Guo L, Chen XZ, Segal Y, Peng JB, Basora N, Babakhanlou H, Cruger G, Kanazirska M, Ye C, et al: Polycystin-2 is a novel cation channel implicated in defective intracellular $\mathrm{Ca}(2+)$ homeostasis in polycystic kidney disease. Biochem Biophys Res Commun 2001, 282(1):341-350

32. Hanaoka K, Oian F, Boletta A, Bhunia AK, Piontek K, Tsiokas L, Sukhatme VP, Guggino WB, Germino GG: Co-assembly of polycystin-1 and -2 produces unique cation-permeable currents. Nature 2000, 408(6815):990-994.

33. Streets AJ, Moon DJ, Kane ME, Obara T, Ong AC: Identification of an Nterminal glycogen synthase kinase 3 phosphorylation site which regulates the functional localization of polycystin-2 in vivo and in vitro. Hum Mol Genet 2006, 15(9):1465-1473.

34. Kottgen M, Benzing $T$, Simmen $T$, Tauber R, Buchholz B, Feliciangeli S, Huber TB, Schermer B, Kramer-Zucker A, Hopker K, et al: Trafficking of TRPP2 by PACS proteins represents a novel mechanism of ion channel regulation. EMBO J 2005, 24(4):705-716.

35. Streets AJ, Needham AJ, Gill SK, Ong AC: Protein kinase D-mediated phosphorylation of polycystin-2 (TRPP2) is essential for its effects on cell growth and calcium channel activity. Mol Biol Cell 2010, 21(22):3853-3865.

36. Sohara E, Luo Y, Zhang J, Manning DK, Beier DR, Zhou J: Nek8 regulates the expression and localization of polycystin-1 and polycystin-2. J Am Soc Nephrol 2008, 19(3):469-476.

37. Praetorius HA, Spring KR: Bending the MDCK cell primary cilium increases intracellular calcium. J Membr Biol 2001, 184(1):71-79.

38. Praetorius HA, Leipziger J: Released nucleotides amplify the cilium-dependent, flow-induced [Ca2+]i response in MDCK cells. Acta Physiol (Oxf) 2009, 197(3):241-251.

doi:10.1186/1471-2369-14-34

Cite this article as: Miyakawa et al: Intracellular calcium release modulates polycystin-2 trafficking. BMC Nephrology 2013 14:34. 